\title{
Response of Haricot Bean (Phaseolus vulgaris L.) to Irrigation Frequency and Intra Row Spacing at Arba Minch, Ethiopia
}

\author{
Teshale Wube' ${ }^{1}$ Amare Girma², Parshotam Datt Sharma² \\ ${ }^{1}$ Arba Minch Agricultural Research Center, Arba Minch, Ethiopia \\ ${ }^{2}$ Plant Science Department, College of Agricultural Sciences, Arba Minch University, Arba Minch, Ethiopia \\ Email: amaregirma2010@gmail.com
}

How to cite this paper: Wube, T., Girma, A. and Sharma, P.D. (2020) Response of Haricot Bean (Phaseolus vulgaris L.) to Irrigation Frequency and Intra Row Spacing at Arba Minch, Ethiopia. Agricultural Sciences, 11, 540-551.

https://doi.org/10.4236/as.2020.116034

Received: March 9, 2020

Accepted: June 2, 2020

Published: June 5, 2020

Copyright ( 2020 by author(s) and Scientific Research Publishing Inc. This work is licensed under the Creative Commons Attribution International License (CC BY 4.0).

http://creativecommons.org/licenses/by/4.0/

\begin{abstract}
Optimizing irrigation frequency and intra row spacing for specific environment is one the major agronomic practices to improve productivity of haricot bean. Hence, a field experiment was conducted to evaluate the effect of irrigation frequency and intra row spacing on growth, nodulation and agronomic performance of haricot bean at Arba Minch during dry season of 2018/19. The treatments consisted of three levels of irrigation frequency based on IW/CPE ratio $(0.5,0.67$ and 1.0) with irrigation depth of $60 \mathrm{~mm}$ and three intra row spacing $(6,10$ and $14 \mathrm{~cm})$ which were factorially arranged in split plot design with three replications. Data were collected on phenological, nodulation, growth, yield and yield related parameters of the crop. The measured parameters were subjected to analysis of variance using SAS software version 9.0. Among the measured parameters, plant height, pod number per plant, dry matter and seed yield were significantly influenced by interaction effect of the treatments. The maximum seed yield $\left(2873.7 \mathrm{~kg} \mathrm{ha}^{-1}\right)$ was recorded with interaction effect of irrigation at IW/CPE of 1 and intra row spacing of $10 \mathrm{~cm}$. As for economic analysis, the same treatment combination also resulted in the highest net benefit (11254.1 Ethiopian Birr ha ${ }^{-1}$ ) and marginal rate of return $(422.1 \%)$. Therefore, it could be concluded that irrigating haricot bean at IW/CPE ratio of 1 and planting at $10 \mathrm{~cm}$ intra row spacing could maximize both seed yield and economic benefit of the crop in the study area.
\end{abstract}

\section{Keywords}

Haricot Bean, Irrigation Frequency, Intra-Row Spacing, Parshall Flume 


\section{Introduction}

Haricot bean (Phaseolus vulagris L.) is an annual crop belonging to the family Fabaceae [1] which is grown predominantly by smallholder producers as a source of food and cash in Ethiopia [2]. The productivity of the crop around the study area $\left(15.7 \mathrm{~kg} \mathrm{ha}^{-1}\right)$ is reported to be below the national average productivity $\left(17.0 \mathrm{~kg} \mathrm{ha}^{-1}\right)[3]$. The low productivity was attributed to different factors like moisture stress, poor agronomic practice, disease and pests and lack of improved technology [4].

Frequency of irrigation which is largely dependent on crop type, soil and climate is reported to significantly affect grain yield of haricot bean [5]. Intra row spacing has also great effect on productivity of haricot bean by affecting its growth and yield components [6].

In the study area, a number of farmers are producing haricot bean besides tomato and onion to fill food gap and generate income by using irrigation during dry season. Production area of the crop is increasing from year to year [7]. Most of the agronomic practices for the crop are based on the recommendations made for rainfed condition, which may not work for irrigated condition. Hence, this study was intended to evaluate the effect of irrigation frequency and intra row spacing on growth, nodulation, yield and yield components of haricot bean at Arba Minch.

\section{Materials and Methods}

\subsection{Description of the Study Area}

The study was conducted at Amibara Farm, Arba Minch, southern Ethiopia, located $505 \mathrm{~km}$ from Addis Ababa, the capital city of Ethiopia, during the dry season of $2018 / 2019$. The geographical location of the farm is $37^{\circ} 36^{\prime} \mathrm{E}$ longitudes and $6^{\circ} 03^{\prime} \mathrm{N}$ latitude and at the altitude of $1218 \mathrm{~m}$.a.s.l. Selected properties of soil are described in Table 1.

\subsection{Treatments and Experimental Design}

The treatments consisted of three levels of irrigation frequency (I1, I2 and I3 corresponding to IW/CPE ratio of $0.5,0.67$ and 1.0) and three levels of intra row spacing $(6,10$, and $14 \mathrm{~cm})$, which were factorially arranged in split plot design with three replications. The IW referred to as fixed irrigation depth $(60 \mathrm{~mm}$ for haricot bean) and CPE was the cumulative pan evaporation ( $\mathrm{mm}$ ). The irrigation frequency was assigned to main plots, whereas intra row spacing was assigned to subplots. Irrigation water (depth) measured by Parshall flume, was delivered to each plot on attaining the given IW/CPE ratio. Nasir variety was selected as a test crop because of its early maturity, better yielding ability, adaptability and wide cultivation in the study area. The size of each experimental main and subplot was arranged by $8 \times 4 \mathrm{~m}$ and $4 \times 2 \mathrm{~m}$ with the total area of $32 \mathrm{~m}^{2}$ and $8 \mathrm{~m}^{2}$, respectively accommodating 5 rows with 66,40 and 28 plants per row corresponding to intra 
Table 1. Soil physico-chemical properties.

\begin{tabular}{|c|c|c|c|c|c|c|}
\hline \multirow{2}{*}{\multicolumn{2}{|c|}{ Physical properties }} & \multicolumn{4}{|c|}{ Soil depth $(\mathrm{cm})$} & \\
\hline & & $0-15$ & $15-30$ & $30-60$ & $60-90$ & \\
\hline \multicolumn{2}{|c|}{ Sand (\%) } & 12.96 & 12.06 & 10.34 & - & \\
\hline \multicolumn{2}{|c|}{ Silt (\%) } & 47.15 & 39.20 & 38.00 & - & \\
\hline \multicolumn{2}{|c|}{ Clay (\%) } & 39.89 & 48.74 & 51.66 & - & \\
\hline \multicolumn{2}{|c|}{ Textural class } & SCL & SC & Clay & - & \\
\hline \multicolumn{2}{|c|}{ Bulk density $\left(\mathrm{Mg} \mathrm{m}^{-3}\right)$} & 1.29 & 1.30 & 1.33 & 1.35 & \\
\hline \multicolumn{2}{|c|}{ Porosity (\%) } & 51.32 & 50.94 & 49.81 & 49.06 & \\
\hline \multirow{2}{*}{ Parameter } & \multicolumn{5}{|c|}{ Chemical properties } & \\
\hline & $\mathrm{OM}(\%)$ & $\mathrm{TN}(\%)$ & $\mathrm{pH}(1: 2.5)$ & Av. P (ppm) & $\mathrm{EC} \mathrm{dS} \mathrm{m} \mathrm{m}^{-1}$ & $\mathrm{CEC}(\mathrm{cmol} / \mathrm{kg})$ \\
\hline Value & 2.88 & 0.21 & 6.37 & 5.57 & 0.23 & 6.45 \\
\hline Rating & Medium & Medium & Slightly acidic & Low & Salt free & Low \\
\hline Reference & & {$[8]$} & & [9] & {$[10]$} & [11] \\
\hline
\end{tabular}

row spacing 6,10 , and $14 \mathrm{~cm}$, respectively. The distance between sub plots and replication were $1 \mathrm{~m}$ and $2 \mathrm{~m}$, respectively. The outer single rows at both sides of the plot and two plants at both ends of the rows were considered as border plants. Nitrogen and phosphorus were applied at planting time at the rate of 30 $\mathrm{kg} \mathrm{ha}^{-1}$ and $20 \mathrm{~kg} \mathrm{ha}^{-1}$, respectively.

\subsection{Data Collection}

The data were recorded on days to $50 \%$ flowering, days to $90 \%$ maturity, plant height $(\mathrm{cm})$, number of branches, total number of nodules plant ${ }^{-1}$, number of effective nodules plant ${ }^{-1}$, nodule dry weight plant $^{-1}(\mathrm{~g})$, number of pods plant ${ }^{-1}$, number of seeds pod ${ }^{-1}$, dry matter $\left(\mathrm{kg} \mathrm{ha}^{-1}\right), 1000$-seed weight $(\mathrm{g})$, seed yield $(\mathrm{kg}$ $\mathrm{ha}^{-1}$ ) and harvest index.

Water-use efficiency (WUE) for each treatment was computed by the following relationship:

$$
\text { WUE }\left(\mathrm{kg} \mathrm{ha}^{-1} \mathrm{~cm}^{-1}\right)=\frac{\text { Economic yield }(\mathrm{kg} / \mathrm{ha})}{\text { Total consumptive use of water }(\mathrm{cm})}
$$

\subsection{Statistical Analysis}

The measured data were subjected to analysis of variance (ANOVA) using SAS software version 9.0. Differences among the treatment means were compared using least significant difference (LSD) test at 0.05 probability level. Correlations among different parameters were carried out by SPSS Software program (version 16).

\subsection{Economic Analysis}

Economic feasibility of the treatments was ascertained by taking cost and ben- 
efit associated with different treatments following the procedures developed by CIMMYT (1988) [12]. For the economic analysis, prevailing labor costs (for planting and irrigation) (@50ETB Man day $^{-1} \mathrm{ha}^{-1}$ ) during the experiment were considered as variable costs and market price of the produce during harvesting stage (@7 ETB $\mathrm{kg}^{-1}$ ) as benefit.

\section{Results and Discussion}

\section{Phenological and Growth Parameters}

Main effect of irrigation frequency and intra row spacing significantly $(\mathrm{P}<$ 0.05) affected phenological parameters and branch number, whereas, treatment interaction did not show any statistical variation in the parameters. On the other hand, plant height and dry matter were significantly $(\mathrm{P}<0.05)$ influenced by interaction effects of the treatments.

\section{Days to $50 \%$ Flowering and $\mathbf{9 0 \%}$ Maturity}

Both the parameters were significantly $(\mathrm{P}<0.05)$ affected by main effects of irrigation frequency and intra row spacing [Table 2]. The minimum significant values of days to $50 \%$ flowering (48.7 days) and days to maturity (65.7 days) were observed due to I1 $(\mathrm{IW} / \mathrm{CPE}=0.5)$ while the maximum significant values of days to $50 \%$ flowering (50.1 days) and days to maturity (69.7 days) were obtained from I3 (IW/CPE $=1)$. Regarding spacing, the minimum significant values of days to $50 \%$ flowering ( 48.7 days) and days to maturity (65.8 days) were observed due to $6 \mathrm{~cm}$ intra row spacing while the maximum significant values of days to $50 \%$ flowering (49.6 days) and days to maturity (69.7 days) were obtained from $14 \mathrm{~cm}$ intra row spacing. However, the effects of $6 \mathrm{~cm}$ and $10 \mathrm{~cm}$ intra row spacing were statistically at par for both parameters. The significant delay in days to maturity with increasing of irrigation frequency and intra row spacing could be associated with availability of growth resources under these conditions, resulting in continued growth and thereby extended physiological maturity of the crop.

Branch number was significantly increased with increase in irrigation frequency increased and intra row spacing [Table 2]. The minimum (4.6) and maximum (5.3) values were recorded under I1 (IW/CPE $=0.5)$ and I3 (IW/CPE $=1)$, respectively. However, the effect of irrigation frequency at I2 $(\mathrm{IW} / \mathrm{CPE}=0.67)$ was statistically at par with I1 (IW/CPE $=0.5)$ and I3 (IW/CPE $=1)$. Said et al. (2018) [11] concluded that frequent irrigation helps to create conducive environment for growth and development of branches through maintaining optimum soil moisture. Similarly, the minimum branch number (4.04) was obtained from narrow intra row spacing $(6 \mathrm{~cm})$ while the maximum number of branches per plant (5.65) was recorded at the widest $(14 \mathrm{~cm})$ intra row spacing [Table 2]. The increase in branch number with increase in intra row spacing might be related to lesser competition for limited growth resources under wider intra row spacing [13]. 
Table 2. Effect of irrigation frequency and intra row spacing on phenology and branch number of haricot bean.

\begin{tabular}{cccc}
\hline Irrigation frequency & Days to $50 \%$ flowering & Days to maturity & Branch number \\
\hline I1 (IW/CPE = 0.5) & $48.7^{\mathrm{a}}$ & $65.7^{\mathrm{a}}$ & $4.6^{\mathrm{a}}$ \\
I2 (IW/CPE = 0.67) & $48.4^{\mathrm{a}}$ & $66.6^{\mathrm{b}}$ & $4.8^{\mathrm{ab}}$ \\
I3 (IW/CPE = 1) & $50.1^{\mathrm{b}}$ & $69.7^{\mathrm{c}}$ & $5.3^{\mathrm{b}}$ \\
LSD (0.05) & 1.3 & 2.46 & 0.51 \\
CV (\%) & 1.9 & 2.8 & 9.6 \\
Intra row spacing (cm) & & & \\
S1 (6) & $48.7^{\mathrm{a}}$ & $65.8^{\mathrm{a}}$ & $4.04^{\mathrm{a}}$ \\
S2 (10) & $49.1^{\mathrm{a}}$ & $66.7^{\mathrm{a}}$ & $5.12^{\mathrm{b}}$ \\
S3 (14) & $49.6^{\mathrm{b}}$ & $69.7^{\mathrm{b}}$ & $5.65^{\mathrm{c}}$ \\
LSD (0.05) & 0.73 & 2.46 & 0.48 \\
CV (\%) & 1.43 & 0.45 & 8.74 \\
\pm SEM & 0.23 & 0.1 & 0.166 \\
\hline
\end{tabular}

Means within each column followed by the same letter(s) are not significantly different at $\mathrm{P}<0.05$; LSD $=$ least significant difference, $\mathrm{CV}=$ coefficient of variation, $\pm \mathrm{SEM}=$ standard error

\section{Plant Height}

Increasing levels of irrigation frequency significantly increased plant height for each level of intra row spacing, whereas, the increasing levels of intra row spacing were associated with significant reduction in plant height for each levels of irrigation frequency [Figure 1]. Accordingly, the tallest plants were observed due to combined effect of frequent irrigation (IW/CPE $=1)$ and narrow intra row spacing $(6 \mathrm{~cm})$ followed by the combined effect of relatively less frequent irrigation $(\mathrm{IW} / \mathrm{CPE}=0.67)$ and narrow intra row spacing $(6 \mathrm{~cm})$. On the other hand, the shortest plants were recorded due to interaction effect of the least frequent irrigation $(\mathrm{IW} / \mathrm{CPE}=0.5)$ with $14 \mathrm{~cm}$ intra row spacing. Increasing irrigation frequency might help to maintain availability of adequate soil moisture around root zone, leading to higher water status and more cell turgidity and internal hydrostatic pressure in the plants. Moreover, the occurrence of taller plants under narrow intra row spacing could be associated with higher accumulation of growth hormone (auxin), resulting in increased cell division and elongation of stem, under competition for light.

\section{Dry Matter}

The maximum dry matter was observed from a combination of frequent irrigation (IW/CPE $=1$ ) with narrow intra row spacing of $6 \mathrm{~cm}$ [Figure 2]. However, the interaction effect of the same irrigation frequency with $10 \mathrm{~cm}$ intra row spacing was at statistical parity. Conversely, the lowest dry matter was obtained from a combined effect of the lowest irrigation frequency $(\mathrm{IW} / \mathrm{CPE}=0.5)$ and closer intra row spacing of $6 \mathrm{~cm}$. This might be ascribed to more moisture stress under less frequent irrigation and greater competition among plants for growth 


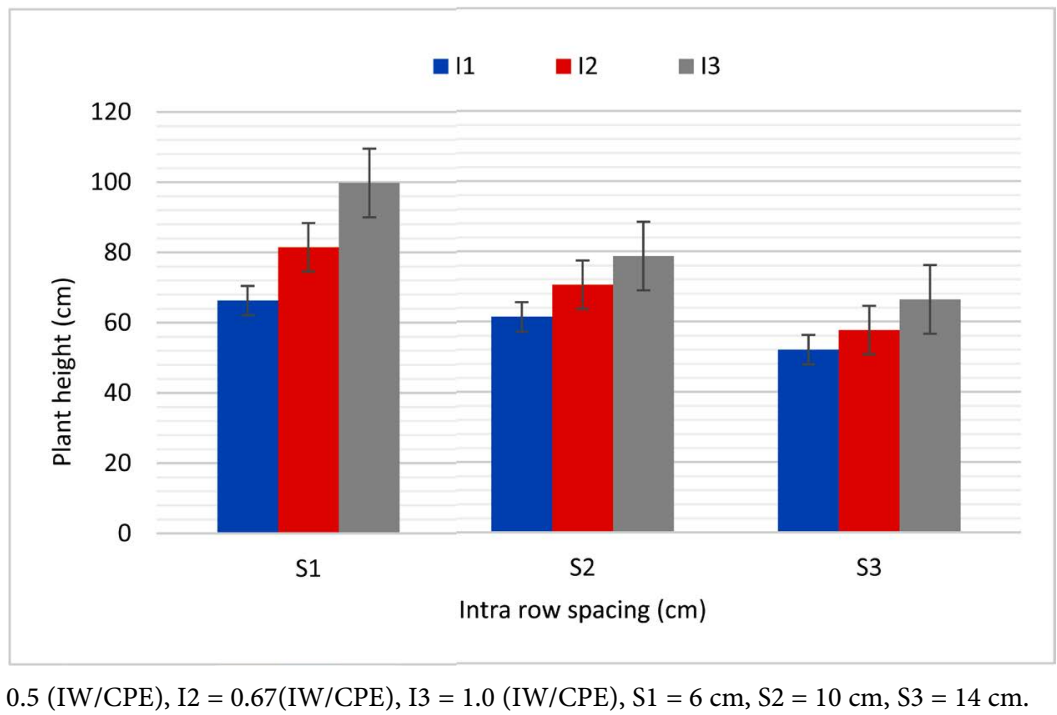

Figure 1. Interaction effect of irrigation frequency $\times$ intra row spacing on plant height of haricot bean. Error bars = standard deviation.

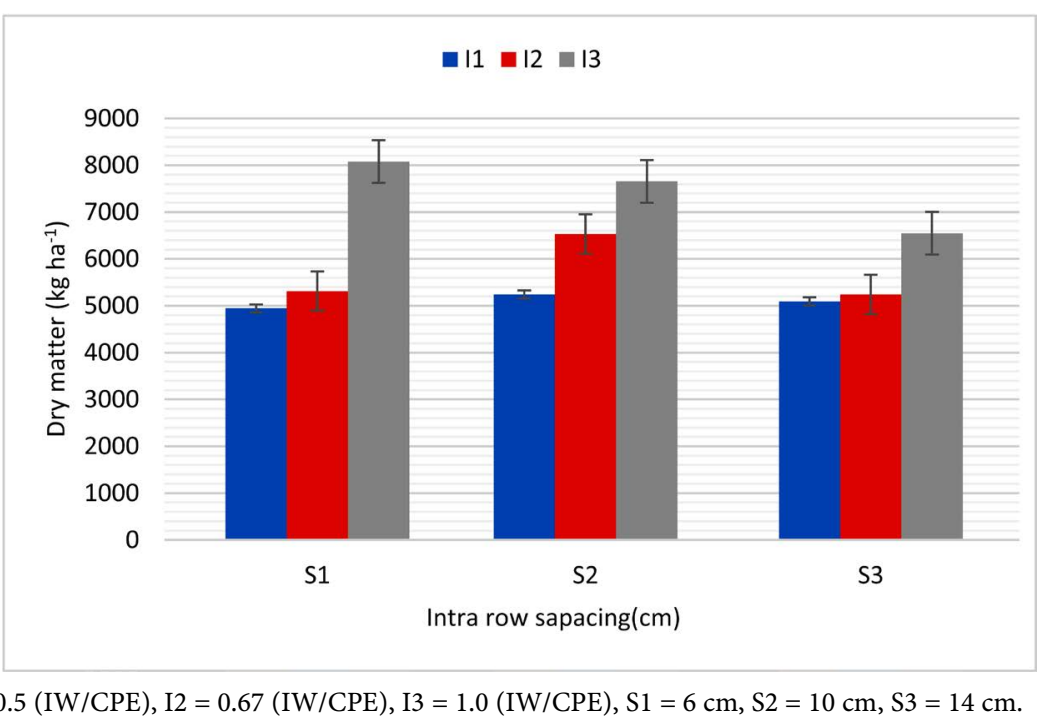

Figure 2. Dry matter of haricot bean as influenced by interaction effect of irrigation frequency and intra row spacing. Error bars = standard deviation.

resources under closer spacing. Solomon et al. (2012) [5] reported that increasing irrigation frequency significantly enhanced above ground biomass yield of bean.

\section{Nodulation}

Nodulation parameters responded significantly only to main effect of irrigation frequency but not to main effect of intra row spacing and its interaction with irrigation frequency. All nodulation parameters were significantly increased with increase in irrigation frequency [Table 3]. Accordingly, the minimum and maximum values of total nodules number (17.4/63.76), effective nodules (8.8/47.26) and nodule dry weight $(0.1 \mathrm{~g} / 0.37 \mathrm{~g})$ were obtained from the lowest 
$(\mathrm{IW} / \mathrm{CPE}=0.5)$ and the highest $(\mathrm{IW} / \mathrm{CPE}=1)$ irrigation frequencies, respectively [Table 3] which might be related to better availability of soil moisture with frequent irrigation [14].

\section{Yield and Yield Components}

\section{Pod Number per Plant}

Pod number per plant was significantly affected by main and interaction effects of the treatments. Interaction of frequent irrigation $(\mathrm{IW} / \mathrm{CPE}=1)$ and closer intra row spacing $(6 \mathrm{~cm})$ produced significantly the highest pod number per plant [Figure 3]. On the other hand, the lowest value was obtained from a combination of the least irrigation frequency $(\mathrm{IW} / \mathrm{CPE}=0.5)$ and the wider $(14$ $\mathrm{cm}$ ) intra row spacing. It was probable as increasing irrigation frequency increased pod number per plant as a result of better growth, evident in increased plant height and dry matter accumulation (Figure 1 and Figure 2), conditioned by better availability of water and nutrients from soil [15].

Table 3. Effect of irrigation frequency on nodulation of haricot bean.

\begin{tabular}{cccc}
\hline $\begin{array}{c}\text { Irrigation } \\
\text { frequency }\end{array}$ & $\begin{array}{c}\text { Total number of } \\
\text { nodules }\end{array}$ & $\begin{array}{c}\text { Number of effective } \\
\text { nodules }\end{array}$ & $\begin{array}{c}\text { Nodule dry weight } \\
(\mathrm{g})\end{array}$ \\
\hline I1 (IW/CPE $=0.5)$ & $17.40^{\mathrm{a}}$ & $8.80^{\mathrm{a}}$ & $0.10^{\mathrm{a}}$ \\
I2 (IW/CPE = 0.67) & $32.96^{\mathrm{b}}$ & $24.15^{\mathrm{b}}$ & $0.23^{\mathrm{ab}}$ \\
I3 (IW/CPE $=1)$ & $63.76^{\mathrm{c}}$ & $47.26^{\mathrm{c}}$ & $0.37^{\mathrm{b}}$ \\
LSD (0.05) & 12.6 & 15.02 & 0.17 \\
CV (\%) & 8.02 & 3.93 & 0.37 \\
\pm SEM & 2.6 & 2.78 & 0.026 \\
\hline
\end{tabular}

Means followed by the same letter(s) in each column are not significantly different at $\mathrm{P}<0.05$, LSD $=$ least significant difference, $\mathrm{CV}=$ coefficient of variation, $\pm \mathrm{SEM}=$ standard error.

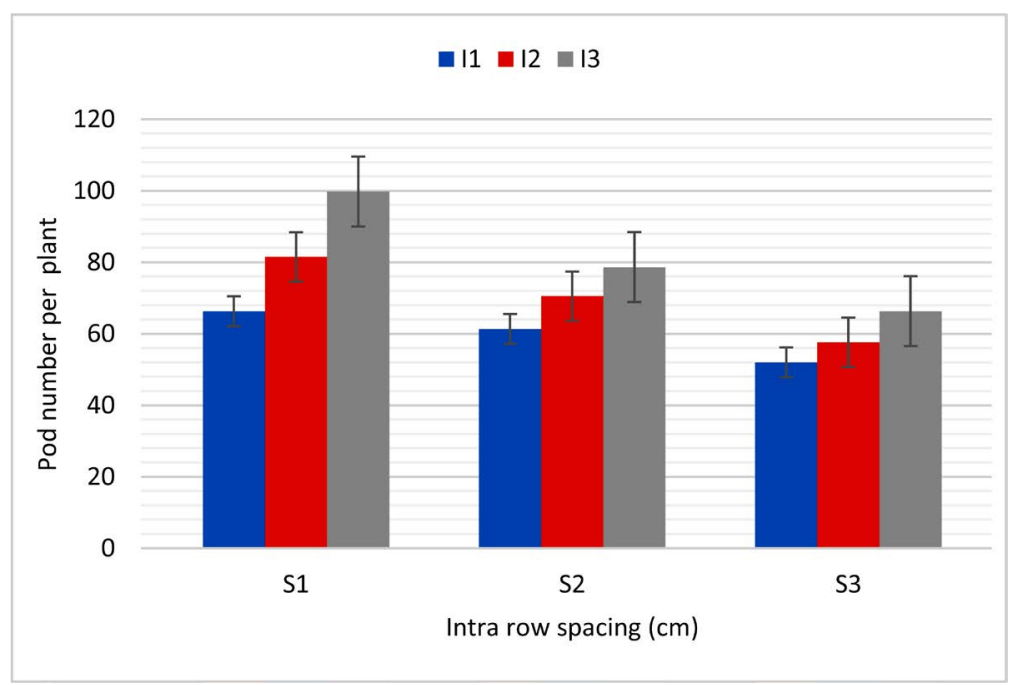

$\mathrm{I} 1=0.5(\mathrm{IW} / \mathrm{CPE}), \mathrm{I} 2=0.67(\mathrm{IW} / \mathrm{CPE}), \mathrm{I} 3=1.0(\mathrm{IW} / \mathrm{CPE}), \mathrm{S} 1=6 \mathrm{~cm}, \mathrm{~S} 2=10 \mathrm{~cm}, \mathrm{~S} 3=14 \mathrm{~cm}$

Figure 3. Interaction effect of irrigation frequency $\times$ intra row spacing on number of pods per plant of haricot bean. Error bars = standard deviation. 


\section{Number of Seed per Pod}

Significant variation in seed number was observed only due to main effects of irrigation frequency which was significantly increased from 3.50 to 5.23 with an increase in irrigation frequency from 0.5 to 1 [Table 4]. This result is in agreement with the finding of Rajanna et al. (2016) [16] who reported significant improvement in seed number per pod with increase in irrigation frequency.

\section{Seed Weight}

Only main effect of intra row spacing was observed to significantly affect 1000 seed weight. Increasing intra row spacing from $6 \mathrm{~cm}$ to $10 \mathrm{~cm}$ was associated with significant improvement in the parameter ranging from 226.66 to $233.78 \mathrm{~g}$, but further increment in the spacing treatment did not bring variation in 1000 seed weight [Table 4]. The improvement in 1000 seed weight with increase in intra row spacing could be associated with creation of better opportunity for plants to utilize and translocate more nutrient thereby enhanced accumulation of food in seed and increased 1000 seed weight. Maguje et al. (2017) [13] also reported improvement in seed weight with increased intra row spacing.

\section{Harvest Index}

Harvest index also significantly responded only to main effect of irrigation frequency. Increasing irrigation frequency up to IW/CPE $=0.67$ was associated with significant improvement in harvest index ranging from 22.30 to 32.04. But, further increment in irrigation frequency did not show significant variation in the parameter [Table 4]. Bourgault et al. (2013) [17] also reported improvement in harvest index with increase in soil moisture.

\section{Seed Yield}

Interaction effect of the irrigation and spacing treatments produced significant variation in seed yield. Significantly minimum and statistically similar values of seed yields were recorded due to interaction effect of the lowest irrigation frequency (IW/CPE $=0.5$ ) with all levels of intra row spacing [Table 5]. On the other hand, significantly the maximum seed yield $\left(2873.7 \mathrm{~kg} \mathrm{ha}^{-1}\right)$ was obtained from interaction of the highest irrigation frequency (IW/CPE $=1$ ) with the intra row spacing of $10 \mathrm{~cm}$. The interaction of the same irrigation frequency level with

Table 4. Effect of irrigation frequency and intra row spacing on yield components of haricot bean.

\begin{tabular}{ccccccc}
\hline Irrigation frequency & NSP & TSW (g) & HI (\%) & Intra row spacing & NSP & TSW (g) \\
\hline I1 (IW/CPE = 0.5) & $3.50^{\mathrm{a}}$ & 228.20 & $22.30^{\mathrm{a}}$ & 6 & 4.10 & $226.66^{\mathrm{a}}$ \\
I2 (IW/CPE = 0.67) & $4.02^{\mathrm{b}}$ & 230.78 & $32.04^{\mathrm{b}}$ & 10 & 4.25 & $233.78^{\mathrm{b}}$ \\
I3 (IW/CPE = 1) & $5.23^{\mathrm{c}}$ & 234.44 & $34.01^{\mathrm{b}}$ & 14 & 4.37 & $233.00^{\mathrm{ab}}$ \\
LSD (0.05) & 0.21 & NS & 3.6 & LSD (0.05) & Ns & 6.84 \\
CV (\%) & 3.74 & 4.04 & 4.04 & CV (\%) & 38.7 & 28.8 \\
\pm SEM & 0.09 & 2.22 & 0.83 & & & \\
\hline
\end{tabular}

Means within a column followed by the same letter are not significantly different at $\mathrm{P}<0.05$, NSP $=$ number of seeds per pod, TSW $=1000$ seed weight, $\mathrm{HI}=$ harvest index, NS $=$ not significantly different at $\mathrm{P}<0.05$. 
$6 \mathrm{~cm}$ intra row spacing produced statistically similar seed yield $\left(2688.7 \mathrm{~kg} \mathrm{ha}^{-1}\right)$ to the former treatment combination. The improvement in seed yield due to irrigation and spacing treatments could be associated with better availability of soil moisture during critical periods resulting in better translocation of photosynthates and accumulation of food into the seeds.

\section{Soil Moisture Depletion (Total Consumptive Use)}

The frequent irrigation (IW/CPE $=1$ ) gave significantly higher value of soil moisture depletion compared to less frequent (IW/CPE $=0.67)$ and least frequent $(\mathrm{IW} / \mathrm{CPE}=0.5)$ irrigations both for $0-30 \mathrm{~cm}$ and $30-60 \mathrm{~cm}$ soil depths [Table 6]. The increases in moisture depletion under frequent irrigation over less frequent and least frequent irrigations were 44 and 84 percent for $0-30 \mathrm{~cm}$ soil depth and 33 and 62 percent for $30-60 \mathrm{~cm}$ depth, respectively. This variation might be due to availability of soil moisture at each soil layer to meet the need of evapotranspiration; plant population probably utilized more water while irrigation water frequently applied. The soil moisture depletion was higher in 0 $30 \mathrm{~cm}$ soil depth compared to $30-60 \mathrm{~cm}$ soil depth [Table 6]. This might be due to more feeder roots extracting water in the upper soil layer.

Table 5. Interaction effect of irrigation frequency and intra row spacing on seed yield (kg $\mathrm{ha}^{-1}$ ) of haricot bean.

\begin{tabular}{cccc}
\hline \multirow{2}{*}{ Intra row spacing $(\mathrm{cm})$} & \multicolumn{3}{c}{ Irrigation frequency } \\
\cline { 2 - 4 } & $\mathrm{I} 1(\mathrm{IW} / \mathrm{CPE}=\mathbf{0 . 5})$ & $\mathrm{I} 2(\mathrm{IW} / \mathrm{CPE}=0.67)$ & $\mathrm{I} 3(\mathrm{IW} / \mathrm{CPE}=1)$ \\
\hline S1 (6) & $1036.3^{\mathrm{d}}$ & $1696.3^{\mathrm{c}}$ & $2688.7^{\mathrm{a}}$ \\
S2 (10) & $1201.3^{\mathrm{d}}$ & $2045.0^{\mathrm{b}}$ & $2873.7^{\mathrm{a}}$ \\
S3 (14) & $1178.0^{\mathrm{d}}$ & $1728.0^{\mathrm{c}}$ & $2031.0^{\mathrm{b}}$ \\
CV (\%) & 7.47 & & \\
LSD (0.05) & 243.03 & & \\
\pm SEM & 79.5 & & \\
\hline
\end{tabular}

Means within each column and rows followed by the same letter are not significantly different at $\mathrm{P}<0.05$.

Table 6. Effect of irrigation frequency on soil moisture depletion.

\begin{tabular}{|c|c|c|c|}
\hline \multirow{2}{*}{ Treatment } & \multicolumn{3}{|c|}{ Soil moisture depletion $(\mathrm{cm})$} \\
\hline & $0-30 \mathrm{~cm}$ depth & $30-60 \mathrm{~cm}$ depth & Total \\
\hline I1 $(\mathrm{IW} / \mathrm{CPE}=0.5)$ & $10.5^{\mathrm{a}}$ & $10.0^{\mathrm{a}}$ & $20.60^{\mathrm{a}}$ \\
\hline $\mathrm{I} 2(\mathrm{IW} / \mathrm{CPE}=0.67)$ & $13.4^{\mathrm{b}}$ & $12.2^{\mathrm{b}}$ & $25.64^{\mathrm{b}}$ \\
\hline $\mathrm{I} 3(\mathrm{IW} / \mathrm{CPE}=1)$ & $19.3^{\mathrm{c}}$ & $16.2^{\mathrm{c}}$ & $35.50^{\circ}$ \\
\hline $\operatorname{LSD}(0.05)$ & 0.68 & 0.34 & 0.89 \\
\hline $\mathrm{CV}(\%)$ & 4.66 & 2.9 & 3.17 \\
\hline \pm SEM & 0.41 & 0.166 & 0.125 \\
\hline
\end{tabular}

Within each column values followed by the same letter are not significantly different at $\mathrm{P}<0.05, \mathrm{LSD}=$ least significant difference, $\mathrm{CV}=$ coefficient of variation, $\pm \mathrm{SEM}=$ standard error. 


\section{Water Use Efficiency (WUE)}

Interaction of irrigation frequency and intra row spacing treatments showed significant $(\mathrm{P}<0.05)$ variation in water use efficiency of haricot bean [Figure 4]. Combined effects of irrigation frequencies: IW/CPE $=1$ with the closest intra row spacing $(6 \mathrm{~cm})$ and $\mathrm{IW} / \mathrm{CPE}=0.67$ with $10 \mathrm{~cm}$ intra row spacing gave higher water use efficiency accounting around $38.7 \%$ higher over the lowest water use efficiency which was registered under interaction of the lowest irrigation frequency $(\mathrm{IW} / \mathrm{CPE}=0.5)$ with $6 \mathrm{~cm}$ intra row spacing [Figure 4]. This might be due to better seed yield obtained in the higher irrigation frequency treatments.

\section{Economic Analysis}

Result of the economic analysis (after elimination of dominated treatment) showed that application of irrigation water corresponding to IW/CPE $=0.67$ and planting haricot bean at intra row spacing of $14 \mathrm{~cm}$ gave the lowest net benefit of $5598.4 \mathrm{ETB} \mathrm{ha}^{-1}$ and marginal rate of return of $157.8 \%$, whereas, irrigating the crop at IW/CPE $=1$ and planting the crop at intra row spacing of $10 \mathrm{~cm}$ resulted in maximum net benefit of $11254.1 \mathrm{ETB} \mathrm{ha}^{-1}$ and marginal rate of return $422.1 \%$ [Table 7].

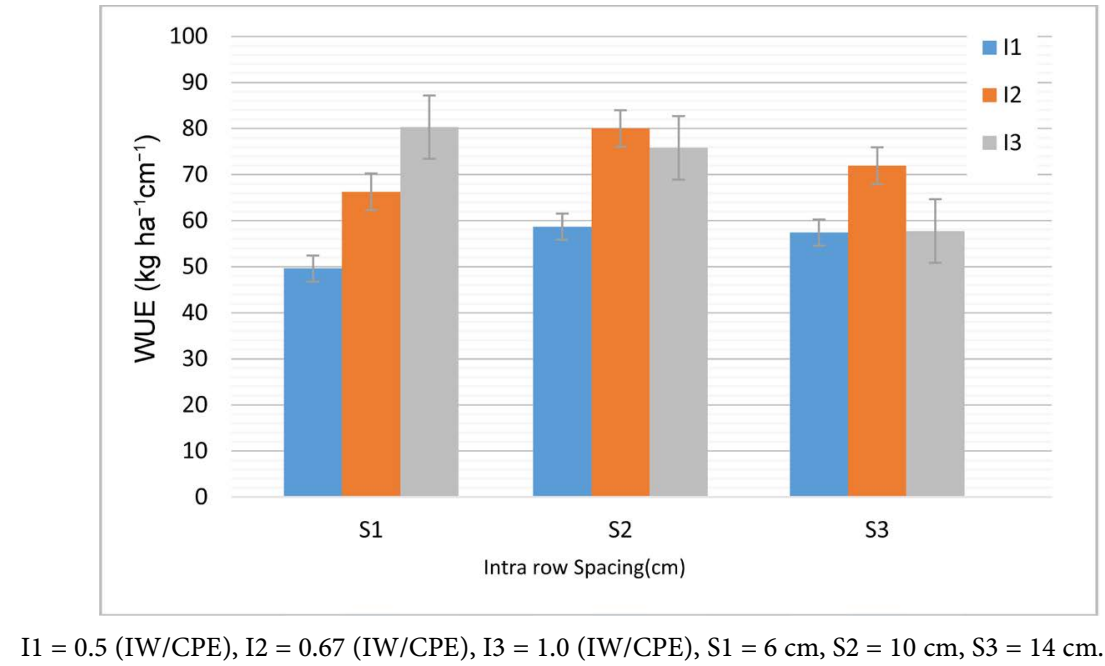

Figure 4. Interaction effect of irrigation frequency and intra row spacing on water use efficiency of haricot bean. Error bars = standard deviation.

Table 7. Marginal rate of return (MRR) analysis of haricot bean production under different irrigation frequency and intra row spacing

\begin{tabular}{ccccccc}
\hline $\begin{array}{c}\text { Treatment } \\
\text { combination }\end{array}$ & $\begin{array}{c}\text { Average } \\
\text { yield } \\
(\mathrm{kg} \\
\left.\mathrm{ha}^{-1}\right)\end{array}$ & $\begin{array}{c}\text { Adjusted } \\
\text { yield } \\
\left(\mathrm{kg} \mathrm{ha}^{-1}\right)\end{array}$ & $\begin{array}{c}\text { Gross benefit } \\
\left(\mathrm{ETB} \mathrm{ha}^{-1}\right)\end{array}$ & $\begin{array}{c}\text { Total } \\
\text { variable } \\
\text { cost } \\
\left(\mathrm{ETB} \mathrm{ha}^{-1}\right)\end{array}$ & $\begin{array}{c}\text { Net benefit } \\
\left(\mathrm{ETB} \mathrm{ha}^{-1}\right)\end{array}$ & $\begin{array}{c}\text { Marginal rate } \\
\text { of return (\%) }\end{array}$ \\
\hline $\mathrm{I} 2 \times 14 \mathrm{~cm}$ & 1728.0 & 1555.2 & 10886.4 & 5288 & 5598.4 & 157.8 \\
$\mathrm{I} 2 \times 10 \mathrm{~cm}$ & 2045.0 & 1840.5 & 12883.5 & 5850 & 7033.5 & 255.3 \\
$\mathrm{I} 3 \times 10 \mathrm{~cm}$ & 2873.5 & 2586.3 & 18104.1 & 6850 & 11254.1 & 422.1 \\
\hline
\end{tabular}

$\mathrm{I} 2=\mathrm{IW} / \mathrm{CPE}=0.67 ; \mathrm{I} 3=\mathrm{IW} / \mathrm{CPE}=1 ; \mathrm{ETB}=$ Ethiopian Birr. 


\section{Conclusion and Recommendations}

Combination of frequent irrigation and $10 \mathrm{~cm}$ intra row spacing significantly improved seed yield $\left(2873.7 \mathrm{~kg} \mathrm{ha}^{-1}\right)$, water use efficiency, net benefit (11254.1 ETB $\mathrm{ha}^{-1}$ ) and marginal rate of return (422.1\%), signifying the possibility of simultaneous maximization of seed yield and economic benefits of haricot bean. Producers in Arba Minch area and elsewhere with similar agro-ecological conditions may, therefore, apply irrigation corresponding to IW/CPE ratio of 1.0 and intra row spacing of $10 \mathrm{~cm}$ for higher productivity and profitability of haricot bean. However, this study was conducted for single season at single location using one variety. Therefore, further research should be conducted considering different varieties, inter row spacing, different fertilizer rates and sources repeated over seasons and locations in order to come up with comprehensive recommendations.

\section{Acknowledgements}

We would like to thank Arba Minch University Research Coordination Office College of Agricultural Sciences for partial funding of this research.

\section{Conflicts of Interest}

The authors declare no conflicts of interest about publication of this paper.

\section{References}

[1] Mohammed, H. (2015) Improving Snap Bean (Phaseolus vulgaris L.) Production under reduced Input Systems. M.Sc. Thesis, University of Saskatchewan, Saskatoon.

[2] Abebe, G. (2009) Effect of NP Fertilizer and Moisture Conservation on the Yield and Yield Components of Haricot Bean (Phaseolus vulgaris L.) in the Semi-Arid Zones of the Central Rift Valley in Ethiopia. Advances in Environmental Biology, 3, 302-307.

[3] CSA (Central Statistics Agency) (2017/18) Report on Area and Crop Production of Major Crops (Private Peasant Holdings, Maher Season). Statistical Bulletin 586. Issue I. Addis Ababa, Ethiopia, 19.

[4] Worku, W. (2015) Haricot Bean Production Guide. The Project Scaling-Up Pulse Innovations for Food and Nutrition Security in Southern Ethiopia, Which Is Supported by the Canadian International Food Security Research Fund (CIFSRF), Hawassa.

[5] Abate, S. (2012) Irrigation Frequency and Plant Density Affect Phenology and Crop Growth of Haricot Bean (Phaseolus vulgaris L.). The African Journal of Plant Science and Biotechnology, 6, 34-39.

[6] Matthews, P.W., Armstrong, E.L., Lisle, C.J., Menz, I.D and Shephard, P.L. (2008) The Effect of Faba Bean Plant Population on Yield, Seed Quality and Plant Architecture under Irrigation in Southern +NSW. In: Unkovich, M.J., Ed., Global Issues, Paddock Action-Proceedings of the 14th Australian Society of Agronomy Conference, Australian Society of Agronomy, Adelaide, South Australia.

[7] AMZWO (Arba Minch Zuriya Woreda Agriculture Office) (2017) Annual Irrigation Achievement Report, Unpublished. 
[8] Tekalign, T. (1991) Soil, Plant, Water, Fertilizer, Animal Manure and Compost Analysis. Working Document No. 13. International Livestock Research Center for Africa, Addis Ababa.

[9] Landon, J.R. (1991) Booker Tropical Soil Manual: Handbook for Soil Survey and Agricultural Land Evaluation in the Tropics and Sub Tropics. Longman Inc., New York.

[10] Ethio SIS (Ethiopia Soil Information System) (2014) Soil Fertility Status and Fertilizer Recommendation Atlas for Tigray Regional State, Ethiopia. Ethio SIS, Addis Ababa.

[11] Hazelton, P.A. and Murphy, B.W. (2007) Interpreting Soil Test Results: What Do All the Numbers Mean? CSIRO Publishing, Australia, 1-152.

https://doi.org/10.1071/9780643094680

[12] CIMMYT (1988) From Agronomic Data to Farmer Recommendations: An Economics Training Manual. CIMMYT, Mexico, 9-59.

[13] Masa, M., Tana, T. and Ahmed, A. (2017) Effect of Plant Spacing on Yield and Yield Related Traits of Common Bean (Phaseolus vulgaris L.) Varieties at Areka, Southern Ethiopia. Journal of Plant Biology \& Soil Health, 4, 13.

https://doi.org/10.13188/2331-8996.1000020

[14] Dasila, B., Singh, V., Kushwaha, H.S., Srivastava, A. and Ram, S. (2016) Water Use Efficiency and Yield of Cowpea and Nutrient Loss in Lysimeter Experiment Under Varying Water Table Depth, Irrigation Schedules and Irrigation Method. SAARC Journal of Agriculture, 14, 46-55. https://doi.org/10.3329/sja.v14i2.31244

[15] Said, S., Mingchi, L., Yanhai, J., Hongju, H. and Nazim, G. (2018) Effect of Irrigation on Growth, Yield, and Chemical Composition of Two Green Bean Cultivars. Horticulturae, 4, 4-10. https://doi.org/10.3390/horticulturae4010003

[16] Rajanna, G.A. Dhindwa, A.S. and Sriharsha, V.P. (2016) Performance of Clusterbean (Cyamopsistetr agonoloba) under Variable Irrigation Schedules and Crop-Establishment Techniques. Indian Journal of Agronomy, 61, 223-230.

[17] Bourgault, M., Madramootoo, C.A., Webber, H.A., Dutilleu, P., Stulina, G., Horst, M.G. and Smith, D.L. (2013) Legume Production and Irrigation Strategies in the Aral Sea Basin: Yield, Yield Components, Water Relations and Crop Development of Common Bean (Phaseolus vulgaris L.) and Mungbean (Vigna radiata (L.) Wilczek). Journal of Agronomy and Crop Science, 199, 241-250.

https://doi.org/10.1111/jac.12016 